\title{
Intravitam Diagnosis of Rabies from Saliva by Nested RT-PCR
}

\author{
M Dandale $^{1}$, C K Singh ${ }^{1}$, B S Sandhu ${ }^{1}$, K Bansal $^{1}$ and N K Sood ${ }^{1}$ \\ ${ }^{I}$ Department of Veterinary Pathology, College of Veterinary Sciences, Guru Angad Dev Veterinary and Animal \\ Sciences University, Ludhiana-141004, India
}

\begin{abstract}
In the present study, rabies was confirmed by Nested RT-PCR on saliva of 24 animals suspected to be rabid. Amplification with first round primers (Rab N1 and Rab N5) yielded a 1477 bp product, while primers used for second round amplification (RabNfor and RabNrev) yielded a 762 bp product. By nested RT-PCR, viral RNA could be detected in $9 / 24(36.0 \%)$ saliva samples. Confirmatory diagnosis by Immunofluorescence performed on brain sample revealed 17 true positive cases. Sensitivity of $68.0 \%$ was recorded by application of Nested RT-PCR on saliva samples. It was concluded that Nested RT-PCR applied on saliva of rabies suspected animal can help in intravitam diagnosis of rabies.
\end{abstract}

Keywords: Immunofluorescence, Intravitam, Nested RT-PCR, Rabies, Saliva.

\section{INTRODUCTION}

Rabies is an acute viral disease that invariably causes fatal encephalomyelitis. In India rabies is enzootic and is a serious public health and economic problem [1].A national multi-centric survey conducted by APCRI in India in collaboration with WHO revealed an incidence of more than 20,000 human deaths per year [2]. The clinical diagnosis of rabies is sometimes suggested by epidemiological (history of exposure) and clinical findings [3]. However, making a reliable diagnosis of rabies based on clinical presentation can be difficult to distinguish from encephalitic condition causes by other viral infections [4]. Therefore, diagnosis is often confirmed late in the course of the disease or postmortem [5]. With the advent of molecular approaches, it is now possible to detect rabies intravitam. Thus, early detection of this dreadful disease is of utmost importance to eliminate number of contacts that require post exposure prophylaxis and expenses of unnecessary diagnostic tests and inappropriate therapy.

Since rabies virus appears in the saliva of dogs before and during the appearance of clinical signs [6], thus molecular approaches can be employed for reliable intravitamdiagnosis on saliva samples. Thus the present study was undertaken to evaluate nested RT-PCR technique for the detection of rabies viral RNA from saliva samples collected from animals suspected to be rabid.

\section{1}

\section{MATERIALS AND METHODS}

Collection of saliva samples

Saliva samples were collected from 24 rabies suspected animals (14 buffaloes, 7 cows and 3 dogs) presented to the Veterinary Clinics, GADVASU, Ludhiana, Punjab and Civil Veterinary Hospital from different districts of Punjab. Soon after the clinical diagnosis was made, the saliva samples were collected either in a sterilized vial directlyor with the help of sterile syringe from oral cavity of animal. Saliva samples obtained from two healthy animals served as negative controls. Rabies positive brain homogenate was used as positive control.

\subsection{RNA extraction and cDNA synthesis}

Total RNA from saliva samples, positive and negative controls was extracted using Qiazol (Qiagen, USA) according to the manufacturer's instructions. The RNA was subjected to cDNA synthesis using a primer RabN1 (30 pmol/ $\mu \mathrm{l}$ ) (Table 1) and subjected to $65^{\circ} \mathrm{C}$ for $10 \mathrm{~min}$ and was later snap cooled on ice and briefly spun down.

CDNA synthesis was done using high-capacity cDNA reverse transcription kit (Applied Biosystems, USA).Reverse transcriptase (Applied Biosystems, USA) mix was prepared and subjected to conditions $25^{\circ} \mathrm{C}$ for $10 \mathrm{~min}, 37^{\circ} \mathrm{C}$ for $2 \mathrm{~h}, 85^{\circ} \mathrm{C}$ for $5 \mathrm{~min}$ and chilling on ice for $5 \mathrm{~min}$ in a thermal cycler (Eppendorf). RNA andcDNAconcentration was measured using Nano Drop Spectrophotometer (Nanodrop Technologies, CA) in $\mathrm{ng} / \mu \mathrm{l}$ and quality was checked as a ratio of OD 260/280.

\subsection{Nested RT-PCR}

The procedure used for the nested RT-PCR was that used earlier $[1,7,8]$ with minor modifications. Briefly, $12 \mu \mathrm{l}$ of cDNA was subjected to a first round amplification using RabN1 and RabN5 primers (30 $\mathrm{pmol} / \mu \mathrm{l}$ ) (Table 1), dNTP's and Taq DNA polymerase for $95^{\circ} \mathrm{C}$ for 2 min followed by 35 cycles of $95^{\circ} \mathrm{C}$ for 1 
$\min , 55^{\circ} \mathrm{C}$ for $1 \mathrm{~min}, 72^{\circ} \mathrm{C}$ for $1 \mathrm{~min} 30 \mathrm{~s}$ and a final extension step at $72^{\circ} \mathrm{C}$ for $5 \mathrm{~min}$. For the second round, $5 \mu 1$ of first round PCR product was amplified with RabNfor and RabNrev (Table 1) by subjecting it to initial denaturation at $95^{\circ} \mathrm{C}$ for $2 \mathrm{mins}$, followed by 35 cycles of $95^{\circ} \mathrm{C}$ for $1 \mathrm{~min}, 50^{\circ} \mathrm{C}$ for $1 \mathrm{~min}, 72^{\circ} \mathrm{C}$ for $1 \mathrm{~min}$ and a final extension step at $72^{\circ} \mathrm{C}$ for $5 \mathrm{~min}$. The amplified PCR products were loaded on agarose gels along with positive control, negative control and DNA ladder (100 base pair plus, Fermentas). The agarose gels were visualized under Geldoc (Bio-Rad) and photographed with the same software.

\subsection{Statistical Analysis}

The sensitivity of nested RT-PCR and Immunofluorescence technique was compared for diagnosis of rabies in Since, Immunofluorescence applied on neural tissue was recommended as gold standard test for diagnosis of rabies by World Health Organization [9]. So, Sensitivity of nested RT-PCR employed on saliva samples was accessed as compared with FAT (Immunofluorescence) performed on brain tissue as under:

$$
\text { Sensitivity }=\frac{\text { True positive }}{\text { True positive }+ \text { False negative }} \times 100
$$

\section{RESULTS}

Quality and concentration of RNA was accessed before cDNA synthesis. Similarly, cDNA was also accessed for purity and concentration before application of Nested RT-PCR.

Amplification with primers Rab N1 and Rab N5 yielded 1477bp first round product. Nested pair of primers (Rab Nfor and Rab Nrev) used for amplification in second round yielded 762 bp product.

The demonstration of viral nucleic acid in saliva by Nested RT-PCR appears to be quite promising for intravitam diagnosis of rabies. By Nested RT-PCR, viral RNA could be diagnosed in 9/25 (36\%) of saliva samples (Table 2). None of the control samples revealed cross- reaction with rabies primer, indicating the specificity of the test.

Confirmation of rabies done by employing immunofluorescence on brain samples revealed 17 true positive cases. Sensitivity of nested RT-PCR on saliva samples was found to be 68\% (Table 3).

\section{DISCUSSION}

Nested RT- PCR is a good alternative for conventional methods as FAT, MIT, or RTCIT for routine rabies diagnosis. FAT is commonly used for post-mortem confirmatory test for rabies diagnosis. However, it has limited intravitam diagnostic value. MIT and RTCIT take a long time and additionally need handling the mice or cell cultures. Another problem is the reduced sensitivity of these methods especially when a sample is in a decomposed state.

Thus, methods applying PCR technology such as RT-PCR, hemi-nested RT-PCR, and real-time PCR due to their rapidity, sensitivity, and reliability are recently more frequently used for rabies diagnosis. Moreover, molecular approaches used by different workers confirmed intravitam diagnosis of rabies viral RNA from saliva [10], skin [11], urine [12], CSF [13] samples.

Rabies viral RNA detected in present study was more as compared to other studies ${ }^{1,10}$ that reported detection of rabies virus in 6/21 (28.57\%) and 11/37 (29.72\%) respectively in saliva samples of human patients by conventional RT-PCR. However, another worker [14] confirmed rabies virus in 9/15 (60.0\%) saliva samples by use of RT-PCR. Another study [15] revealed higher rabies viral RNA in 47/62 (75.80\%) saliva samples by nucleic acid amplification based technique. However, findings of another study [8] confirmed rabies viral RNA in 3/12 (25.0\%) saliva samples of animals by nested RT-PCR which was less as compared with the present study.

\section{TABLES}

Table 1: Primers used for Nested RT-PCR

\begin{tabular}{|c|c|c|c|c|}
\hline Primer Name & Sequence & Gene & Positions & Sense \\
\hline Rab N1 & $\begin{array}{l}5^{\prime} \text { GCTCTAG AAC ACC TCT } \\
\text { ACA ATG GAT GCC GAC } \\
\text { AA 3' }\end{array}$ & $\mathrm{N}$ & $59-84$ & + \\
\hline Rab N5 & $\begin{array}{l}\text { 5' GGA TTG AC(AG) AAG } \\
\text { ATC TTG CTC AT 3' }\end{array}$ & $P$ & 1514- 1536 & - \\
\hline RabNfor & $\begin{array}{l}5^{\prime} \text { TTG T(AG)G A(TC)CA } \\
\text { ATA TGA GTA CAA 3' }\end{array}$ & $\mathrm{N}$ & $135-156$ & + \\
\hline RabNrev & $\begin{array}{l}\text { 5' CTG GCT CAA ACA TTC } \\
\text { TTC TTA 3' }\end{array}$ & $\mathrm{N}$ & $876-896$ & - \\
\hline
\end{tabular}


Intravitam Diagnosis of Rabies from Saliva by Nested RT-PCR

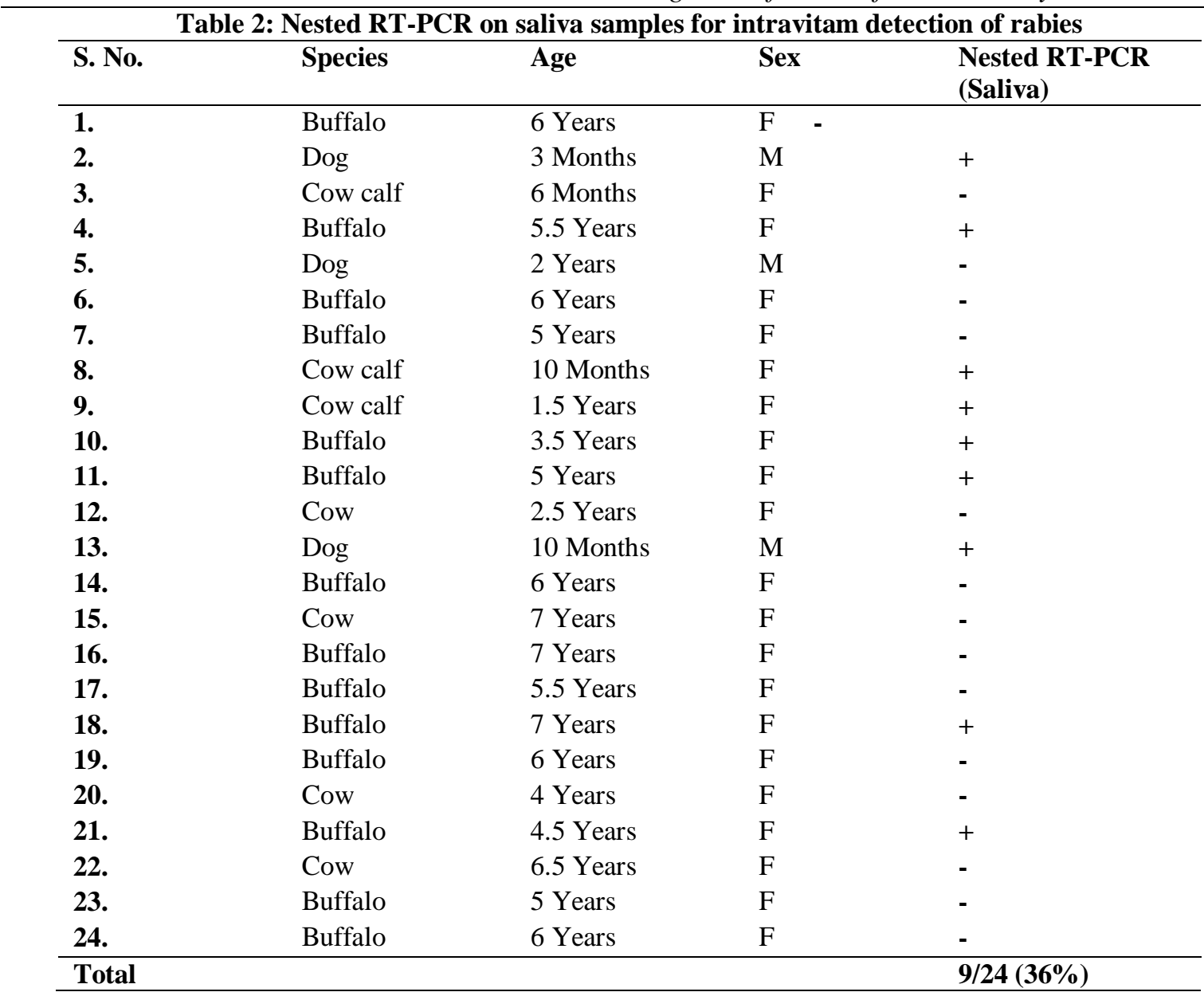

+ Positive, - Negative, M-Male, F-Female

Table 3: Sensitivity comparison of Nested RT-PCR on saliva with FAT on brain.

\begin{tabular}{cccc}
\hline Test & $\begin{array}{c}\text { FAT on brain } \\
\text { smears } \\
\text { (Positive) }\end{array}$ & $\begin{array}{c}\text { FAT on brain } \\
\text { smears } \\
\text { (Negative) }\end{array}$ & Total \\
\hline $\begin{array}{c}\text { Nested RT-PCR on saliva } \\
\begin{array}{c}\text { (Positive) } \\
\text { Nested RT-PCR on saliva } \\
\text { (Negative) }\end{array}\end{array}$ & 9 & 0 & 9 \\
\hline Total & 8 & 7 & 15 \\
\hline
\end{tabular}

Sensitivity $=$ True Positive $/$ True Positive + False Negative $\times 100=17 / 17+8=68.0 \%$

\section{CONCLUSION}

So far, conventional method (Immunofluorescence) applied on brain samples is used as confirmatory tool for diagnosis of rabies, but with the advent of molecular approaches rabies can also be diagnosed intravitam. The present study concludes that Nested RT-PCR used on saliva samples is a useful, specific, sensitive and better molecular approach and can be used as future diagnostic tool for early diagnosis of rabies thus prevents post exposure prophylaxis and unnecessary treatment. This study also clears the pathways for future studies, that sensitive Nested RT-PCR technique could be used on various ante-mortem samples like milk, urine, skin biopsy, CSF etc. for intravitam diagnosis of dreadful rabies.

\section{ACKNOWLEDGEMENTS}

Authors are grateful to Dr. S N S Randhawa, Director of Research, GADVASU for providing the necessary research facilities and Director Animal Husbandry for sponsoring research scheme entitled "Development of Research-cum-Diagnostic laboratory for Rabies". 


\section{REFERENCE}

[1] T. Nagaraj, P. V. Joel, A. Desai, A. Kamat, S. N. Madhusudana and V. Ravi. Ante mortem diagnosis of human rabies using saliva samples: Comparison of real time and conventional RT-PCR techniques, Journal of Clinical Virology, 36, 2006, 17-23

[2] M. K. Sudarshan, S. N. Madhusudana, B. J. Mahendra, N. S. Rao, D. H. Narayana and S. A. Rahman. Assessing burden of human rabies in India: results of a national multi-centre epidemiological survey. International Journal of Infectious Diseases, 11, 2007, 2935 .

[3] T. Hemachudha. Human rabies: clinical aspects, pathogenesis, and potential therapy, In (edn.): Lyssaviruses, edited by Rupprecht CE, Dietzschold B, and Koprowski H, 1994 Springer-Verlag, Berlin, Germany.

[4] R. W. Emmons. Rabies diagnosis and rabies vaccine. Northern England Journal of Medicine, 301, $1991,331-332$.

[5] D. B. Fishbein, J. S. Smith, C. E. Rupprecht and K. Clark. Unexplained rabies in three immigrants in the United States. A virologic investigation. Northern England Journal of Medicine, 324, 1991, 205-11.

[6] L. G. Schneider. Spread of virus from the central nervous system. In: Baer, G.M. (Ed.),The Natural History of Rabies. Academic Press, 1975, New York, 273-301.

[7] S. A. Nadin-Davis, Polymerase chain reaction protocols for rabies virus discrimination. Journal of Virological Methods, 75, 1998, $1-8$.

[8] A. Kaw, C. K. Singh, B. S. Sandhu, N. K. Sood, Ramneek, D. Deka and S. Awahan, Diagnosis of rabies in animals by Nested RTPCR, Indian Journal of Animal Sciences, 81(4), 2011, 367-369.

[9] A. C. Hanlon, S. J. Smith and R. G. Anderson. Article II: Laboratory diagnosis of rabies, Journal of American Veterinary Medical Association, 215, 1999, 1444-1447.

[10] P. Crepin, L. Audry, Y. Rotivel, A. Gacoin, C. Caroff and H. Bourhy. Intravitam diagnosis of human rabies by PCR using saliva and cerebrospinal fluid. Journal of Clinical Microbiology, 36, 1998, 1117-1121.

[11] L. Dacheux, J. M. Reynes, P. Buchy, O. Sivuth, B. M. Diop, D. Rousset, C. Rathat, N. Jolly, J. B. Dufourcq, C. Nareth, S. Diop, I. C. R. Rajerison, C. Sadorge and H. Bourhy. A Reliable Diagnosis of Human Rabies Based on Analysis of Skin Biopsy Specimens. Clinical Infectious Diseases, 47, 2008, 1410-1417.

[12] S. Wacharapluesadee and T. Hemachudha. Urine as a source of rabies RNA detection in human rabies diagnosis. Clinical Infectious Diseases, 34, 2002, 874-5.

[13] W. Saengseesom, C. Mitmoonpitak, S. Kasempimolporn and V. Sitprija. Real-time PCR analysis of dog cerebrospinal fluid and saliva samples for ante-mortem diagnosis of rabies. Southeast Asian Journal of Tropical Medicine and Public Health, 38(1), 2007, 53-57.

[14] D. L. Noah, C. L. Drenzek, J. S. Smith, J. W. Krebs, L. Orciari, J. Shaddock, D. Sanderlin, S. Whitfield, M. Fekadu, J. G. Ol son, C. E. Rupprecht and J. E. Childs. The epidemiology of human rabies in the United States, 1980-1996. Annals of International Medicine, 11, 1998, 922-930.

[15] S. Wacharapluesadee and T. Hemachudha. Ante-mortem and post-mortem diagnosis of rabies using nucleic acid-amplification tests. Expert Review Molecular Diagnosis, 10(2), 2010, 1-12. 